\title{
KIITOS JUKKA JA AULIS
}

\section{K un Aikuiskasvatus-lehteä 1980-luvun alussa}

suunniteltiin ja päädyttiin lopulta sen perustamiseen, saatettiin hyvin perustellusti sanoa, että lehti eläisi enintään puolisenkymmentä vuotta. Lähdettiin taistelemana niukoin taloudellisin kehyksin valmiina tekemään kaikki mahdollinen, jotta ennusteista huonot estettäisiin toteutumasta.

Tässä yhteydessä on mieluisaa mainita toimitussihteerien lisäksi päätoimittajaksi valittu ja sittemmin tehtävää vuoden 1991 loppuun saakka yksitoista vuotta hoitanut Jukka Tuomisto. Hänen työllinen työnsä lehden jok'ikisen numeron tekemiseksi on ylittänyt massiivisesti sen, mihin päätoimittajat yleensä ovat valmiit. Jukka Tuomisto panosta lehden hyväksi voi verrata vapaan sivistystyön pioneerien työhön: tehtävään innosti vakaumuksellinen usko sen mielekkyyteen; se vaati tavattomasti aherrusta ja vaivannäköä. Vastikkeeksi se tarjosi sisäisen tunnon siitä, että on kyseessä tärkeä työ.
M yös toinen Aikuiskasvatuksen Tutkimusseu1 ran edustaja, Aulis Alanen, jätti vuoden vaihteessa lehden toimituskunnan. Monien lehden numeroiden suunnittelussa mikään ei oikein olisi voinut korvata sitä aikuiskasvatuksen käytännön ja teorian asiantuntemusta, joka Aulis Alasella on. Aivan erityisesti voi tuntea kiitollisuutta siitä, että hän panoksellaan piti lehdessä yllä sellaisia aihepiirejä, jotka ovat perustavan tärkeitä, mutta jotka olisivat saattaneet jäädä muutoin kokonaan huomiotta aikuiskasvatuksen arjen kuormittamalle lukijalle.

$\mathbf{K}$ aikilla niillä, jotka tekevät Aikuiskasvatus-lehteä nyt ja tulevaisuudessa, on hyvät lähtöasetelmat ja edellytykset lehden kehittämisessä kaiken sen urakan jälkeen, mitä lehden yksitoistavuotisen alkutaipaleen aikana on tehty. 